\title{
Wasting Breath in Hamlet
}

\author{
Naya Tsentourou
}

\begin{abstract}
This chapter draws on instances of disordered breathing in Hamlet in order to examine the cultural significance of sighs in the early modern period, as well as in the context of current work in the field of medical humanities. Tracing the medical history of sighing in ancient and early modern treatises of the passions, the chapter argues that sighs, in the text and the performance of the tragedy, exceed their conventional interpretation as symptoms of pain and disrupt meaning on the page and on stage. In the light of New Materialist theory, the air circulating in Hamlet is shown to dismantle narratives of representation, posing new questions for the future of medical humanities.
\end{abstract}

Keywords Hamlet $\cdot$ Sighs $\cdot$ Breath $\cdot$ Air - Emotions • Medical humanities

A. Rose et al., Reading Breath in Literature, Palgrave Studies in Literature, Science and Medicine, https://doi.org/10.1007/978-3-319-99948-7_3 
CLAUDIUS: There lives within the very flame of love

A kind of wick or snuff that will abate it;

And nothing is at a like goodness still;

For goodness, growing to a pleurisy,

Dies in his own too-much. That we would do,

We should do when we would; for this 'would' changes,

And hath abatements and delays as many

As there are tongues, are hands, are accidents,

And then this 'should' is like a spendthrift's sigh

That hurts by easing. But to the quick of th'ulcer.

(4.7.112-21, Appendix A in the Oxford edition)

Delivered in conspiratorial confidence by Claudius to Laertes, urging him to avenge the death of Polonius by murdering Hamlet in a fatal duel, these lines appear in the second quarto of Hamlet (1604) but are removed from the First Folio edition (1623) of the play. According to the Oxford editor, G.R. Hibbard, "the excision of these lines from F is a gain" as they unnecessarily prolong Claudius's interrogation of Laertes's intentions and his insistence on ensuring the wronged son's commitment to revenge. While the extract might be superfluous to the progress of the play's performance, the lines remain faithful to the tragedy's preoccupation with excess of passion, and its potential to consume the individual incapable of moderation. ${ }^{1}$ The moral imperative to revenge is communicated via means of popular knowledge: editors are quick to acknowledge that the phrase "like a spendthrift's sigh / that hurts by easing" refers to the idea "that every sigh a man breathes costs him a drop of blood and thus wastes part of his life." ${ }^{2}$ The folkloric origins of the concept are generally adopted by editions of the play as early as the eighteenth century, with Samuel Johnson glossing the line as "a sigh that makes an unnecessary waste of the vital flame. It is a notion very prevalent, that sighs ... wear out the animal powers." 3 Moreover, editors are often prone to draw on other examples from the Shakespearean canon where sighing is perceived as consuming blood: we find cross-references to 2 Henry 6 with sighs described as "blood-consuming" and "blood-drinking" (3.2. 60-4), to 3 Henry 6, where sighs are called "blood-sucking" (4.5. 21-4), and to A Midsummer Night's Dream where "sighs of love cost the fresh blood dear" (3.2.97). "While they agree on the cultural capital of the phrase, editors disagree on whether the line in Hamlet should read a "spendthrift's sigh" or "a spendthrift sigh." In the first case, advocated by the Arden editors and found in the original quarto, 
the sigh refers to the prodigal man's regret of having spent his money. In the second case, adopted by Hibbard, the sigh itself is the spendthrift, problematising a figurative reading and raising questions about bodies and their potential to self-destruct. ${ }^{5}$

Even as Claudius projects a distant and undefinable future where Laertes's sigh becomes a synonym of regret, physiological sighs are absent from the stage. The king digresses, wasting breath and words, having to recollect himself and resume focus "to the quick of th'ulcer." The textual reference to sighing does not record a symptom or incite a stage direction, as is often the case in the play; the sigh here is positioned between the physiological and the emotional, yet escapes both by being proverbial. It has been rendered axiomatic, validated by observations of both the expelled air and its wasteful effect on the suffering individual. At the same time, it has transformed into shared medical knowledge derived culturally and transmitted on and off stage via Shakespeare, his characters and his editors. Its encyclopaedic aura is of the empirical style found in a treatise like Francis Bacon's Sylva Sylvarum (1627), where sighing is defined as "caused by the drawing in of a greater quantity of breath to refresh the heart that laboureth: like a great draught when one is thirsty." Claudius, like another natural philosopher or physician, has assigned meaning to his observations which he has fixed with a simile allowing no deviation between points $\mathrm{A}$ and $\mathrm{B}$ of the comparison, and is reiterating common knowledge on disrupted patterns of breathing. Shakespeare's editors, comparing the lines to other instances of wasteful sighs in Shakespeare, follow suit.

The proverbial waste of the body is one of the narrative ways in which the play figures and reconfigures disrupted breathing. In other instances, sighs communicate emotional states such as grief and pain, the exaggerated rhetoric and theatricality of a lover, and, ultimately, the final moments of one's life. In the second part of the chapter, I show how the deeply inhaled and exhaled air, which, according to Claudius, "hurts by easing," blurring pain with relief and cause with remedy, destabilises in the process the very narratives it seeks to validate. In examining how disrupted breath dismantles representation, my underlying question, arising in the context of this volume and in its engagement with medical humanities, shifts from "what can sighing mean?" to "how does sighing mean?" on stage and in early modern scientific circles.

My analysis of sighing in Hamlet is informed by the revisionist agenda of New Materialism and the model of entanglement that accompanies its 
recent adoption by scholars of the history of emotions and the Critical Medical Humanities alike. In the last two decades, New Materialism has begun to (re)adjust humanist and social constructivist theories and practices that have emphasised human agency, or the lack thereof, and have reproduced rigid boundaries between nature and culture, and between human and non-human matter. ${ }^{7}$ Influential voices, such as Karen Barad, object to materialist discourse (including Foucault's and Butler's) which delineates matter to a definitive and measurable existence or apparatus, carefully separated from and existing outside the realm of human activity, language and behaviour. For Barad, "matter is neither fixed and given nor the mere end result of different processes. Matter is produced and productive, generated and generative. Matter is agentive, not a fixed essence or property of things." 8 When Gertrude sighs at the beginning of Act 4 in Hamlet, Claudius's adoption of an external observation point to evaluate the "matter" of her breathing ("There's matter in these sighs, these profound heaves; / You must translate. 'Tis fit we understand them" [4.1. 1-2]) proves inadequate. The king seeks to immediately place Gertrude's audibly and visually distressed body within an epistemological framework that will explain her sighs and what they represent. His project is one of urgent translation: of transporting the sighs from the world of things to the world of words, despite Gertrude's insistence in the scene directly preceding Claudius' entry that "if words be made of breath / And breath of life, I have no life to breathe / What thou hast said to me" (3.4. 195-7)..$^{9}$ For the New Materialist Barad, the representationalism Claudius perpetuates is characteristic of Newtonian metaphysical individualism and humanism and "never seems to get any closer to solving the problem it poses because it is caught in the impossibility of stepping outward from its metaphysical starting place."10 Likewise, Gertrude's embodiment of frantic breathing on stage cannot be observed from a privileged exterior position; her sighs are neither only words nor only things: "things don't pre-exist ... outside of particular agential intra-actions, 'words' and 'things' are indeterminate. Matter is therefore not to be understood as a property of things but, like discursive practices, must be understood in more dynamic and productive terms - in terms of intra-activity." "ll How we might resist the humanist temptation to quantify and account for sighs in strictly representational terms, and how, on the other hand, we might feel them as phenomena that performatively iterate their materiality are the driving concerns of this chapter. ${ }^{12}$ 
Intra-activity in Hamlet complicates and implicates the material existence of audience and actors, of observers and performers, of the theatre and the world. Emotional breathing escapes the confines of the dramatic text and flows between page, stage and audience in unpredictable, yet inclusive, circles. Breath belongs to, and is determined by, the affective fabric of the original playtext as much as it is by the actor's present and living body, while the recycling process of inhaling and exhaling reaches out to implicate the spectators, whom, according to Carolyn Sale, breath animates: "what they receive renders them active, or rather creates in them the capacity or the potential to become that which they observe: the breath makes them 'capable' by turning them all into potential actors." 13 Carolyn Sale and Carla Mazzio both draw on the materiality of air and breath in their analyses of Hamlet. Mazzio argues that the word "matter" in Claudius's command maintains its definition as substance, and specifically, "air": "an element packed with atoms ... a medium through which other elements ... could move or be moved ... a central medium of intellection and communication." 14 In a tourde-force analysis of the history of air in and through Hamlet, Mazzio examines how Renaissance artists, including Shakespeare, Dürer and Donne, negotiated their physical existence and their art in a world whose air was as inspiring as it was vertiginous in a period that prefigured the Enlightenment's quest for conquering air via an array of scientific instruments. The technologies that sought to master air are for Mazzio kin to "an aesthetics of affect [that] emerged out of, and often managed to displace concerns about, the otherwise threatening power of an element that could not be directly seen, understood, controlled, or subjected to "capture." 15 Sale transfers the discussion of the physics and metaphysics of air back to the materiality of the Renaissance stage, outlining a theory of performance that rests on the transmission of breath between actors and audiences "in a play so insistently about the material." 16 Mazzio's and Sale's studies, however, tend to re-inscribe the boundaries they aim to interrogate, treating the matter of air as a separate, albeit circulating, substance, impacting on the cultural parameters of the age and the stage. In what follows, I will reformulate their historical materialism with the aim to articulate "active process[es] of materialization of which embodied humans are an integral part, rather than the monotonous repetitions of dead matter from which human subjects are apart."17

Reading breath in Hamlet, and sighing in particular, as "dead matter" which the human participants of a performance re-enact and put to use 
reduces it to an instrumental role that obscures its "vitality," "preventing us from detecting (seeing, hearing, smelling, tasting, feeling) a fuller range of the nonhuman powers circulating around and within human bodies." 18 The character of Hamlet, aware of the potential of his own body to be used as a vessel for one's breath and to serve the purposes of others, refutes the instrumentalisation of air matter.

HAMLET: It is as easy as lying. Govern these ventages with your fingers and thumb, give it breath with your mouth, and it will discourse most eloquent music. Look you, these are the stops.

...

You would play upon me! You would seem to know my stops, you would pluck out the heart of my mystery, you would sound me from my lowest note to my compass. And there is much music, excellent voice, in this little organ. Yet cannot you make it speak. 'Sblood! Do you think I am easier to be played on than a pipe? Call me what instrument you will, though you fret me you cannot play upon me. (3.2. 349-63)

In exposing the scheming intentions of his childhood friends, Rosencrantz and Guildenstern, and refusing to act as the pipe into which air will be passively channelled and invested with external meaning, Hamlet resists the assumption that breath is the mere manipulation of air. One of the first things we learn about Hamlet is that he does not waste sighs in vain, and is indeed wary of those who use their breath in instructed and artificial ways. He states so in his first appearance, where he enlists breathlessness as an actor's tool.

HAMLET: Seems, madam - nay, it is, I know not 'seems'.

'Tis not alone my inky cloak, cold mother,

Nor customary suits of solemn black,

Nor windy suspiration of forced breath,

No, nor the fruitful river in the eye,

Nor the dejected haviour of the visage,

Together with all forms, moods, shapes of grief

That can denote me truly. These indeed 'seem',

For they are actions that a man might play,

But I have that within which passes show,

These but the trappings and the suits of woe. (1.2.76-86)

Listing what "seems" against "that within which passes show" Hamlet condemns the validity of the performative elements of grief, from 
funereal garments and material accessories to mournful physical expressions, including the "windy suspiration of forced breath." The Oxford English Dictionary marks Hamlet's comment here as the first example where the term "suspiration" refers to "(deep) breathing." 19 In his sarcastic rejection of what he perceives to be Gertrude and Claudius's feigned sorrow, Hamlet chooses to emphasise grief's manifestation through corporal air, resulting in and from sighs, by drawing attention to its evaporating and insubstantial nature. The compressed circulation and expulsion of air from the body is identified as a universal symptom of grief, but the double meanings in "windy" (relating to the wind and frivolous, bombastic and unsubstantial) and in "forced" (violently expelled and feigned), as well as the context of Hamlet's speech, render breathlessness insincere. Hamlet's response undermines the validity of forced breath as a symptom, as a sign on which we can fix meaning and put order to an experience, try to understand it, reset and refresh it.

Hamlet's rejection of the distancing effect of this kind of representation contrasts with one of the most affective moments in the tragedy, where the wasteful energy of suspiration is securely (though falsely) embraced in Ophelia's account of Hamlet's appearance in her closet, reported to Polonius in Act 2, Scene 1:

OPHELIA: ...

At last, a little shaking of mine arm

And thrice his head thus waving up and down,

He raised a sigh so piteous and profound

As it did seem to shatter all his bulk

And end his being. (2.1. 89-93)

Ophelia's lines are delivered in a state of shock and apparent distress after her meeting with Hamlet: she enters the scene "affrighted" (2.1.72) and "fear[s]" (2.1.82) Hamlet has gone mad. Whether the part is performed in a frantic or stunned manner, her report carries an emotional intensity that in most productions is interpolated with her disrupted breaths (due to haste of delivery and/or edginess), and makes the encounter vivid in the audience's mind. Although we can only imagine Hamlet's sigh, directors might opt for Ophelia to embody in her gestures the sigh that shutters Hamlet. Both Katie West, in Sarah Frankcom's Hamlet (Royal Exchange, Manchester, 2014), and Natalie Simpson, in Simon Godwin's production (RSC, Stratford-Upon-Avon, 2016), for instance, pointed to their stomach with tense hand gestures as they brought that 
sigh to life, a nod perhaps to the notion prevalent in the period that bowels are "the seat of the tender and sympathetic emotions." 20 The wasting of blood Claudius mentions to Laertes is here reinvented as the emptying and annihilation of the body, an inevitable effect of turbulent sighing, leading Polonius to declare his verdict:

\section{POLONIUS: ...}

This is the very ecstasy of love,

Whose violent property fordoes itself

And leads the will to desperate undertakings

As oft as any passions under heaven

That does afflict our natures. (2.1.99-103)

That the body appears to be wasting itself in sighing allows Polonius to offer a satisfactory, for his purposes, explanation and to categorise Hamlet's breath under passionate, and thus violent, love melancholy. Hamlet's, and Ophelia's for that matter, disordered state is neatly regulated by her father, who seeks to make known what he perceives is hidden in Hamlet's interior: "This must be known which, being kept close, might move / More grief to hide than hate to utter love" (2.1. 115-16). Polonius has created a narrative out of the loss of air that Hamlet purportedly performs via Ophelia's body and account.

Constructing narratives of sighing as wasteful yet restorative has been a traditional practice of the health sciences from antiquity to the twenty-first century. In early medical theory, sighing is benign rather than threatening, its main purpose being to cool and refresh the labouring heart and to revive the vital spirits, becoming a close synonym to respiration in general. Discussions of respiration before the experiments of Boyle and Hooke in the second half of the seventeenth century relied predominantly on Aristotelian and Galenic models of physiology, both classical paradigms that took breathing as a cooling agent for the body's innate heat. ${ }^{21}$ In Timaeus, one of the earliest Western accounts of the mechanism of respiration, Plato, expanding on Empedocles before him, argued that

as the heart might be easily raised to too high a temperature by hurtful irritation, the genii placed the lungs in its neighbourhood, which adhere to it and fill the cavity of the thorax, in order that the air vessels might moderate the great heat of that organ, and reduce the vessels to an exact obedience. ${ }^{22}$ 
Following his example, Aristotle wrote in On Respiration that "as the chest rises, the air from outside must flow in, as it does into the bellows, and being cold and refrigerative quench the excess of fire. ... it enters in cold and passes out hot, because of its contact with the heat." 23 For Galen, too, the body's heat can only be "sustained by way of the 'ventilation' of the body due to the influx of the external air's refreshing quality throughout the body." 24 As far as the beginnings of Western physiology are concerned, there seems to be little scientific interest in sighs in particular, but it does appear in discussions of emotions which cause turbulent respiration. As early as the third century BC Alexander of Aphrodisias, a leading Peripatic philosopher and commentator of Aristotle, answering "why doe such as are in griefe, and in love, and in anger, sigh very oft?", argues that a sigh is actually produced when the body, due to excessive passion, forgets to act according to its regular routine:

Because that the soule and minde of such as are grieved, is turned into the cause of griefe and sorrowe ... the soule then being intentive upon that whither she moveth, doth after a sort neglect \& forget to give motive vertue and power unto the muscules of the breast. Therefore the heart not receiving aire by opening of the breast, \& by a consequence neither blowing not cooling, ... the heart, I say, doth force the minde and give her warning, that she would give more motion unto the muscles, and cause greater breathing in and out, and that she would take more store of colde ayre, and thrust out more excrements, and that often small breathings would performe that that one great one may effect. And therefore men of oldtime; called the word suspirio sighing, of the straitnes of the breast. ${ }^{25}$

When confronted with and immersed in excessive sorrow or love, sighing is the heart's solution to the negligence and numbness of the mind, seeking to restore the balance that has been disrupted by the stillness of the chest. The body appears to lose its cognitive abilities and to sleep, forgetting itself, until the suffocating heart moves to a sudden motion. The notion that sighing is an impulsive and abrupt movement of the emotionally overwhelmed heart trickles down to the Renaissance and our familiar treatises of passions. These customarily list sighing as a symptom of melancholy, whether in the form of green-sickness or intellectual and religious melancholy. Thomas Wright, for instance, in The Passions of the Mind (1604) describes the effects of sadness on the body by suggesting that it floods the heart with melancholy blood and in doing so threatens to dry it: "The cause why sadnesse doth so moove the forces of the body, 
I take to be, the gathering together of much melancholy blood about the heart, which collection extinguisheth the good spirits, or at least dulleth them." 26 The dried, dull, contracted heart, lacking moisture, has to sigh, as Timothy Bright's Treatise of Melancholie (1586) affirms: "sighing hath no other cause of moving than to coole and refreshe the hearte, with fresh breath, and pure aire, which is the nourishment and foode of the vital spirites, besides the cooling which the heart it selfe receiveth thereby." 27 Sighs attributed to love melancholy work in similar ways as Nicholas Coeffeteau writes in his Table of Humane Passions (1621), reminding us of the self-forgetfulness that Alexander of Aphrodisias talks about:

His soule that loves intirely, is perpetually imployed in the contemplation of the party beloved, and hath no other thoughts but of his merit, the heate abandoning the parts, and retiring into the braine, leaves the whole body in great distemperature, which corrupting and consuming the whole bloud, makes the face grow pale and wane, causeth the trembling of the heart, breds strange convulsions and retires the spirits ... followed with passionate and heart-breaking sighes. ${ }^{28}$

For Jacques Ferrand's Erotomania (1640), sighs are symptoms of green-sickness but they also gesture towards a process of recollection, being initiated by "Nature" to rectify the absent-mindedness of "strong Imaginations":

Sighing is caused in Melancholy Lovers, by reason that they many times forget to draw their breath, being wholy taken up with the strong Imaginations that they have, either in beholding the beauty of their Loves, or else, in their Absence, contemplating on their rare perfections, and contriving the meanes how to compasse their Desires. So that at length recollecting themselves, Nature is constrained to draw as much Aire at once, as before it should have done at two or three times. And such a Respiration is called, a Sigh; which is indeed nothing else, but, a doubled Respiration. ${ }^{29}$

In premodern accounts of emotions, sighs are interpreted the moment they are exhaled as solid evidence of a complex and rather violent procedure the body has to undergo to tackle its own dis-ease. Sighing emerges as be the body's natural and instinctive cure, offering relief, comfort ("it may seeme probable that the sobbing and sighing ... if they be not vehement and long ... drawing in of fresh aire, geue also some comfort") and even pleasure that approximates self-indulgence ("it is certaine, that 
even in cares and vexation, there is also a content in the teares and sighes wee powre forth for the absence of that wee loue"). ${ }^{30}$

The air that is deeply inhaled and exhaled affords the opportunity to read but also to generate meanings, a performative quality that undercuts the expression of love Polonius matches with sighing. Welcoming Rosencrantz's invitation to the players, Hamlet proclaims that the actor playing "the Lover shall not sigh gratis" (2.2. 319), attesting to voluntary sighing as a rhetorical trope for courtship. In fact, Polonius himself might have this tradition of inauthentic sighing in lovesickness in mind, when, in Act 1, warning Ophelia against accepting Hamlet's promise of love, he instructs her:

POLONIUS: In few, Ophelia, Do not believe his vows, for they are brokers Not of that dye which their investments show, But mere implorators of unholy suits Breathing like sanctified and pious bonds The better to beguile. (1.3. 125-30)

Hamlet's personified vows are perceived as assuming a devout and spiritual exterior that is facilitated and communicated to Ophelia via his breath. The textual instability here in "bonds," where the Arden editors read it as "bonds" (i.e. written or verbal promises), but Oxford editors following Theobald who amended it to "bawds" in his 1726 edition, alerts us to breathe as hypocritical both in a religious and in a secular context. On a side note, if we accept the word to be "bawds," the lines open up interesting questions about prostitution and the corruption of air, another central preoccupation of the play that dramatises the "foul and pestilent congregation of vapours" (2.2. 268-9). Moreover, advising Raynold how to engage in espionage of his son, Laertes, Polonius again uses "breath" to refer to hypocritical words and to the spread of unsubstantiated rumours. Hamlet the play and Hamlet the protagonist are intrigued by the elusive nature of sighing and suspend uncomplicated readings of the air communicated between bodies. In this respect, the play participates in the construction and production of knowledge of respiration rather than transmit it only. Sighs can be instrumental, hypocritical, self-shattering, emotional, escaping definitions that early modern medical discourses seek to fix by closing the gap between the air that escapes the human body and the inner cause or effect of it. 
Current medical research on sighs affirms their dominant function as survival mechanisms that control and regulate the disordered body, and acknowledges their significance as critical for life: "the sigh plays a role in monitoring brain state changes, controlling arousal, and homeostatically regulating breathing variability."31 In February 2016, biochemists succeeded in isolating the exact part of the brain area controlling the respiratory system that is in charge of sighing, revealing that these "two tiny clusters of nerve cells in the brain's stem ... act in response to an unconscious command to reinflate as necessary the myriad tiny sacs in the lungs called alveoli, which control the body's traffic in oxygen and carbon dioxide, and which sometimes collapse." 32 Recently, biologists have been "able to completely eliminate sighing from normal breathing in rodents by ablating the central sigh control circuit: several days after removing sighs, their breathing became irregular, confirming a true necessity of sighing." 33 While the physiological attributes of sighing have been confirmed to the degree that we know we could not survive if we did not sigh at least every five minutes, sighing's relationship to our emotional health is not as straightforward. According to research by a group of psychologists in the last decade, "respiratory variability and psychological states are closely related, supporting the hypothesis that sighing may play an important role as resetter of both." ${ }^{4}$ Scientists have examined how "expanding the lungs by sighing causes relief of dyspnea and associated chest tightness and restlessness," 35 demonstrating that sighing "causes release of physiological and/or psychological tension" and that it helps the body recover from mental stress. ${ }^{36}$ They have even observed similarities and differences between spontaneous and instructed sighs in order to test to what extent instructed sighs can be used to replicate the positive effects of relief associated with spontaneous sighing. At the same time, "instructed sighing is generated behaviourally instead of chemically, possibly leading to dysregulation instead of regulation" and proving potentially "maladaptive" while not resulting in release of muscle tension characteristic of spontaneous sighing. ${ }^{37}$ Like Bright, who warns against vehement sighs in the Renaissance, writing that, "if they be vehement, then shake they the hart and midriffe too much, and cause a sorenesse about those partes," 38 these studies find that "although the respiratory system may benefit from sighing, when randomness becomes too high, excessive sighing may disregulate the system." 39 
In their introduction to The Edinburgh Companion to the Critical Medical Humanities, Anne Whitehead and Angela Woods assert the importance of bringing the past to bear upon current debates in the health sciences. According to the authors, historical perspectives "offer alternative vantage points from which to view, reflect on and critique the biomedical," "enable us to attend to different forms of qualitative critical thinking - and different ways to sensing our world - that were important in the past and that may remain with us today" and "help us to understand the extended, continual and shifting process of negotiation through which certain objects and practices come to our attention and others fade from view." ${ }^{40}$ When premodern theories are placed next to modern scientific investigations of sighs, the separation between "words" and "things," or between human activity and matter, is shown to have persisted. The narrativising of sighs and the pathologising of the body in early modern and modern accounts rely on the observers standing outside suspiration, observing it, measuring it by its effects and experimenting with it. The continuity of interpreting sighs as an activity, a "thing" for which science will supply the words, attests to a reading of the body and its air as objects, not as phenomena. ${ }^{41}$ This is disturbingly evident, for example, in research conducted on non-human mammals for the purposes of understanding human emotionality. In their attempt to track sighing's relation to emotion, $\mathrm{Li}$ and Yackle include the following case: "when rodents are trained to associate auditory tone with an electric tail shock and a light with the omission of the shock, they sigh more when the omission signal is played during the shock signal, which is interpreted as a sigh of relief." 42 Rodents, sound, light and electric shocks constitute an apparatus that for the scientists "provides an important gateway into understanding how emotional sighs, and therefore emotions, are generated." 43 The human factor in this experiment, while the main target of the research, is reduced to its technological instruments as if absent from the stimuli and conditions the rodents find themselves in. Human emotion is investigated as distinct-mirrored in the emotion of other mammals but not associated with its production.

In the search of scientific evidence for the interaction (as opposed to New Materialism's model of intra-action) between sighs and emotions, boundary-making spreads from the human/animal division to discipline demarcations. One study takes as its starting point the fact that "sighs have inspired philosophers, musicians, and poets for several centuries," 
listing Shakespeare and Bach as examples of "the artists' early understanding of the deeper nature of the sigh." 44 The article concludes that "one day we as scientists will be able to catch up with the great artists who have long appreciated the important role of the sigh in regulating our emotions." 45 The hailing of the arts as instinctively attuned to the behavioural role of sighs presupposes (a) that the arts allow access to a different type of knowledge than the sciences, and (b) that this knowledge is somewhat covert and ineligible until the sciences "catch up" with measuring it and making it available. "We can trust that Shakespeare already knew that sighs are not just augmented breaths" implies that the playwright knew sighs were more than that, but what "that" might be remains hidden. ${ }^{47}$ But what if the question of who (person or discipline) knows what about sighing is irrelevant? Adopting entanglement rather than division as a research model disturbs the dynamic between sighs and emotions, confusing the representational readings of sighing offered by Claudius and Polonius and sought after by sciences. As explored earlier in this chapter, Hamlet foregrounds the instability and artificiality of ascribing meaning to the air that escapes the human body. As a result, the "corporeality of emotion," its physiological embodiment by individuals and the language used to express this, loses its privileged position in debates of materiality. ${ }^{48}$ What we are left with, instead, is sighing as a phenomenon that enacts the boundaries it is said to signify. It does not tell the story of pain or love or sorrow, it does not reorder and reset a body out of tune, but exceeds these perceived functionalities, intraacting within bodies, air, stage structures.

Refusing instrumentalisation, breath in theatre enables alternative configurations. On stage, sighing is fake and real at the same time; the air is enacted but it is also organic, produced and productive. Its exploration requires an interdisciplinary and entangled approach, relating to and exceeding the history of emotions, the history of medicine, current biological and psychological insights, as well as the affective technologies Steven Mullaney has used to refer to the stage, thinking of theatre in other words as a key mechanism in generating and transmitting collective emotions, in which we are part of the (theatrical) apparatus, not standing on the edges of it. ${ }^{49}$ Hamlet does not rest at a definition of sighing as a symptom that accompanies emotional or physical suffering, but offers us an example of sighing as "emotional practice." Anthropologist Monique Scheer, building on the work of William Reddy and Barbara Rosenwein, has historicised emotions by applying Pierre Bourdieu's concept of 
habitus, a "system of cognitive and motivating structures"50 on which she expands as follows: "people move about in their social environments ... in most cases supremely practiced at the subtleties of movement, posture, gesture, and expression that connect them with others as well as communicate to themselves who they are." 51 Sighs, in this respect, which in affect theory would traditionally be classified as "automatic behaviours, reflexes, spontaneous responses," can be "more fruitfully thought of as habits emerging where bodily capacities and cultural requirements meet." 52 What makes "emotional practice" a pertinent designation for sighing is the underlining principle that "the physiological contains both the organic and the social, which cooperate in the production of emotion," 53 undermining purist attachment to the body as well as social determinism. Entangled materiality in Hamlet affirms (while contradicting) Scheer's point that "emotions cannot be conjured out of thin air"54; in Hamlet they are air.

Reformulating the interactive relationship between sighs and emotions as the intra-active reality of sighs entangled with emotions disrupts the narrative of sighing in the play as restoring meaning or reordering an experience. ${ }^{55}$ As we have seen, modern terminology of resetting and reinflating seems to share with Renaissance medical discourse a focus on the reorganisation of the body; a reordering of what has been in disorder that in the process can be either life-threatening or life-affirming. Medical writings on sighing try to reset, regulate, refresh, recover, reinflate and reorganise the emotionally and mentally distressed body. In doing so, scientific discussions of distorted breathing can be thought of as producing a narrative of knowledge that relies on air, or else, on what comes in and out of the body, but does not remain. The symptom, sighing, is revealed to be not only elusive and unfixed (its instability most pronounced in the fact that it is also a cure), but it escapes location in a specific part of the body; it is instead found in the body's waste, in what the body expels and rejects, in what is figured as the outside rather than the inside. The "spendthrift sigh" and Claudius's reference to it in the context of delayed and unsatisfactory action allude to what is no longer there, a "should" that has been supplanted by a "would," an ethical commitment to revenge that has been indefinitely postponed, a sigh that has already been wasted. The breath that regulates simultaneously wastes the human body as Shakespeare's Richard II reminds us listing sighs as an abject substance; alongside his tears and groans, sighs control the rhythmic functions of the cyborg human clock into which Richard has transformed: 
RICHARD: I wasted time, and now doth Time waste me;

For now hath Time made me his numb'ring clock.

My thoughts are minutes, and with sighs they jar

Their watches on unto mine eyes, the outward watch,

Whereto my finger, like a dial's point,

Is pointing still, in cleansing them from tears.

Now, sir, the sound that tells what hour it is

Are clamorous groans which strike upon my heart,

Which is the bell. So sighs, and tears, and groans

Show minutes, times, and hours. But my time

Runs posting on in Bolingbroke's proud joy,

While I stand fooling here, his jack o'the clock. (Richard II, 5.5. 49-60)

Richard's sighs become the mechanical indicators of time passing, shocking the body by materialising his inward thoughts every minute, projecting or ejecting them ("jar their watches unto mine eyes") to the outside. ${ }^{56}$ Examining sighs translates into ordering disordered breathing, but this process is communicated as knowledge of loss. Forcefully expelled from the body, and registering the body's resignation, sighing can be seen to embody death, as Brandon LaBelle has argued exploring the "oral imaginary" or else the ways that the mouth gestures: "the sigh" he writes, "is a sort of rehearsal of one's dying moment: it shadows the body's ultimate gasp, that final sound and respiration." 57 Emptying the body the moment they are expelled, sighs can only be experienced as loss. As a result, writing of suspiration and attempting to capture it, or better recapture it, ultimately succumb to a type of representation whereby loss of air can only be accounted for by attempts to repossess it.

Representation evaporates. In a speech shortly before he dies, Hamlet's final plea with Horatio is for an orchestrated sigh, one that is produced pathologically in pain but turns into wasted air into the play we see in front of us:

\section{HAMLET: As thou'rt a man}

Give me the cup. Let go. By heaven, I'll have't.

O God, Horatio, what a wounded name,

Things standing thus unknown, shall I leave behind me!

If thou didst ever hold me in thy heart,

Absent thee from felicity awhile,

And in this harsh world draw thy breath in pain,

To tell my story. (5.2. 327-33) 
This scene is usually delivered with Hamlet dying in Horatio's hands, sighing often and heavily due to the physical exhaustion of the duel with Laertes and the fact he has been wounded by him with a poisoned sword. In most productions, Hamlet's exhaustion is accentuated after physically struggling to stop Horatio from committing suicide either by shouting, running over to him or even wrestling for the cup. Knowing these are Hamlet's final moments, we as the audience are invited to pay close attention to every word he speaks, perhaps-depending on seating arrangements - suspending our breathing patterns to catch his last words, and what is hard to ignore is the prince's heavy breathing, in some cases coupled with Horatio's heavy breathing, the sighs of both locked and exchanged between them. Actors and audience are breathing together and are short of air at the same time, a shared emotional and suffocating experience. Sale has argued that Hamlet asks to breathe through Horatio who will communicate his breath to the audience, but my understanding is that Hamlet in asking Horatio to "draw his breath in pain" is asking him specifically to sigh. ${ }^{58}$ Sighing in this respect is called upon to assume the role of storytelling, of representing, of constructing narratives out of one's private experience and of ordering what has been in disorder - all of which sighs are perceived to do. And yet, considering the temporality of each theatrical production that reorders, rehearses, repeats and re-enacts, Hamlet epitomises the slippery significations of sighing and the experience of loss inherent in all representation. This loss is always inevitable but never absolute in the world of the theatre and in the world of Hamlet. Having witnessed Hamlet's evaporating final breath and its channelling through Horatio onto the atmosphere of the playhouse, our emotions work to sustain the illusion of Hamlet's dead body and to overlook the actor's now quiet rhythmical movement of the chest. As Carol Rutter writes with regard to Cordelia's corpse, "speechless, motionless, reduced by death from somebody to the body, the corpse, the actor's body occupies a theatrical space of pure performance where it has most to play when it has least to act. It is a subject-made-object whose presence registers absence and loss." ${ }^{59}$ What refuses the transition from subject to object is breath, the unmistakable sign of life outside the control of any actor, that restores the dead body of the character to its vitality even after it has exhaled its dying groan.

But Hamlet's dying groan refuses to be a sign of death. In its indeterminacy and visible invisibility, his last gasp of air is neither his last nor a gasp but exceeds both, as it revitalises matter and eludes representation. 
The "O, O, O, O" line that appears in the First Folio after Hamlet's words "The rest is silence" (5.2. 342) is not found in the second quarto and has allowed for scholarly speculation by editors and critics. Hibbard, in his Oxford edition, chooses to replace the line with the stage direction "he gives a long sigh and dies," whereas the Arden editors, faithful to the second quarto, relegate the four Os to the footnotes and call them "a conventional indication of a dying groan or sigh." Investigating stage history, Tiffany Stern has suggested that the line found in the Folio but not in the good quarto might have been added by the Shakespearean actor, Richard Burbage:

could it be that Burbage, playing Hamlet, wanted a more glamorous death-scene than the one the text gave him? As it appears, Burbage has frustrated the wishes of the author for a reflective, silent death, by imposing on to his part a noisily vocal death-rattle, though it ruins the tenor of the last lines. ${ }^{60}$

Stern assigns multiple meanings to the sigh: it is an extravagant indication of death, it is loud and noisy, it is disrespectful to the silent, sacred death scene Shakespeare intended, and it is symptomatic of an actor's virtuosic performance and an opportunity for them to elide authorial control. When juxtaposed with an actor's perspective, however, and experience of delivering the elusive line, editorial interventions to pin down its meaning can be seen as part of an apparatus that measures and delineates but remains detached from the phenomenon of sighing that unfolds on stage. In a 2009 radio interview, Mark Rylance was asked to comment on whether these four sounds represent "a nothingness or something."61 Sighing audibly and on cue before offering his answer, Rylance struggled to explain away the sighs he enacted. After deliberation and pausing often, his response was that the "O,O,O,O" is the moment (or the four distinct moments) of "encountering another reality than was immediate apparent to those around me" 62 but one that cannot be captured in words: "his [Hamlet's] ability to put words to what he's witnessing dies before his ability to witness." 63 In place of the narrative that breaks down, the sigh's energy explodes in unpredictable material directions: on some occasions, Rylance would deliver the line "silently, looking four times in four different places," or he would "change tempo," but he admits that the "best deaths" occurred on nights "when audience and I were together" aware that "something is happening but 
we do not know what it is, then he [Hamlet] is gone." 64 Including the line in the text is giving air a boundary, circumscribing it, describing it, representing it, closing it down and measuring it, yet on stage, on radio and in life the Os of a sigh are constantly expelled, absorbed, having no boundaries.

\section{Notes}

1. Not all editors agree with the excision; Thompson and Taylor have retained this passage for the Arden. Hibbard's glosses of lines 4.7. 112-121 appear in the Appendix A in the Oxford edition (2008), which is the edition this essay refers to when citing from Hamlet.

2. Hamlet, 367.

3. Walsh $(1997,173)$.

4. See Malone (1821, 454-456).

5. For a full discussion of editorial proceedings of this line and passage, see Walsh 173-174.

6. $\operatorname{Bacon}(1627,184)$.

7. Katie Barclay, for instance, has made this case for historians of emotions: "relationships, networks, histories become 'matter', while leaving matter behind or unidentified." Barclay $(2017,179)$.

8. $\operatorname{Barad}(2007,137)$.

9. OED online: to bear, convey or remove from one person, place or condition to another; to transfer, transport.

10. Barad $(2007,137)$.

11. Ibid., 150.

12. For the distinction between objects/objectivity (traditionally seen as having exterior, separate and clearly defined material boundaries) and phenomena (open-ended practices of reconfiguration that characterise intra-action), see Barad, chapter 3, esp. 146-175. As Barad states in her introduction, "phenomena do not merely mark the epistemological inseparability of observer and observed, or the results of measurements (in other words, objects); rather, phenomena are the ontological inseparability of agentially intra-acting components. Significantly, phenomena are not mere laboratory creations but basic units of reality" (33, Barad's emphasis).

13. Sale $(2006,157)$.

14. Mazzio (2009, 169-170).

15. Ibid., 154.

16. Ibid., 148 .

17. Coole and Frost $(2010,8)$.

18. Bennett (2010, ix). 
19. OED online.

20. Ibid.

21. See West (2014); for an admittedly brief discussion of respiration in the Renaissance, see Lindeman (1999); for a detailed history, see Murray Kinsman (1927).

22. Quoted in West (2014, L122).

23. Aristotle, transl. by W.S. Hett (1936, XX, 479b, 17-XXI, 480b, 12).

24. Debru $(2015,273)$.

25. Alexander of Aphrodisias (1595, XXII, K4).

26. Wright $(1604,61)$.

27. Bright $(1586,158)$.

28. Coeffetaeu (1621, 171-172).

29. Ferrand (1640, 133).

30. Bright, 161, and Coeffetaeu, 273.

31. Ramirez $(2014,17)$.

32. Radford (2016); see also Krasnow and Feldman (2016).

33. Li and Yackle (2017, R89).

34. Vlemincx et al. (2010a, 86).

35. Ibid., 86 .

36. Vlemincx et al. "Take a Deep Breath" $(2010 b, 72)$; see also Vlemincx et al. $(2015,664-665)$.

37. Ibid., 72 .

38. Bright $(1586,161)$.

39. Vlemincx et al. "Take a Deep Breath" $(2010 b, 68)$.

40. Whitehead and Woods $(2016,7)$.

41. Barad makes the distinction between objects and phenomena in her study.

42. Li and Yackle (2017, R89).

43. Ibid., R89.

44. Ramirez $(2014,3)$.

45. Ibid., 17.

46. "The idea of the medical humanities having a 'role' to play within a wider research ecology presupposes the sanitary division of disciplines rather than the messy and mixed hybridities, collaborations and dilutions that underpin much of its work" (Viney et al. 2015, 4).

47. Ramirez $(2014,3)$.

48. Barclay $(2017,180)$. The bodily experience of emotions has been the subject of multiple studies on early modern literature and drama (including Shakespeare) since the turn of the century. The materialism of new historicist readings of the passions in the renaissance, despite its influential challenge to the dualistic boundaries of Pauline theology and to symbolic interpretations of the body, has itself been on the receiving end of criticism. Richard Strier, for instance, has reacted to the work 
of Gail Kern Paster and Michael C. Schoenfeldt for what he sees as an insistence on using humoral theory as the master-discourse of the period and in effect pathologising the subject, privileging the embodied interiority of passions (see, for instance, Paster 2004; Paster et al. 2004; and Schoenfeldt 1999). According to Strier, the "new humoralism" of this critical school "produces readings that are extraordinarily and consistently conservative, readings that entirely support the rule of order, reason, and restraint" (17-18). Robert S. White and Ciara Rawnsley recently remind us that "specific circumstances and affective responses become more complex than such an approach can accommodate" (241). The revisionary tendencies of renaissance scholarship articulated in the last decade have emerged in the context of wider scepticism about the "affective turn," or else about the movement in neurosciences, psychology and philosophy that developed in the turn of our century with thinkers like Antonio Damasio, and their influence on figures, such as Brian Massumi, who focused on the body's autonomous capacity to respond, interact and feel prior to the brain's application of any cognitive interpretative strategies. Yet, as Ruth Leys argues, the validation of the body as the pure, pre-conscious, determinant has come at the expense of endowing its experiences with any meaning: "what we are witnessing today is the embrace by the new affect theorists in the humanities and social sciences of the same anti-intentionalism that for more than twenty years now has been entrenched in the sciences of affect" (469).

49. See Mullaney $(2007,74)$.

50. Quoted in Scheer $(2012,201)$.

51. Scheer (2012, 201-202), see also Reddy (2001), Rosenwein (2006), and Plamper (2010).

52. Ibid., 201-202.

53. Ibid., 207.

54. Ibid., 219.

55. There's again a point to be made here about the use and the limits of narrative in medical humanities, as advocated by Angela Woods (2011).

56. See Shakespeare, King Richard II (2002).

57. LaBelle $(2014,85)$.

58. Sale $(2006,161-162)$.

59. Rutter $(2001,2)$.

60. Stern $(2004,89)$.

61. Rylance $(2009, \min 5$, sec 30-38).

62. Ibid., $\min 6$, sec $10-30$.

63. Ibid., $\min 6$, sec $40-46$.

64. Ibid., $\min 7, \sec 1-35$. 


\section{REFERENCES}

Alexander of Aphrodisias (although Aristotle is listed as the author). 1595. Physitians. Edinburgh: Printed by Robert Waldgrave.

Aristotle. 1936. On Respiration, trans. W.S. Hett. The Loeb Classical Library. Cambridge: Harvard University Press.

Bacon, Francis. 1627. Sylva Sylvarum: Or, A Natural History in Ten Centuries. London: Printed for W. Lee.

Barad, Karen. 2007. Meeting the Universe Halfway: Quantum Physics and the Entanglement of Matter and Meaning. Durham: Duke University Press.

Barclay, Katie. 2017. New Materialism and the New History of Emotions. Emotions: History Culture, Society 1: 161-183.

Bennett, Jane. 2010. Vibrant Matter: A Political Ecology of Things. Durham: Duke University Press.

"bowel." OED Online. Oxford: University Press. www.oed.com. Accessed 26 Apr 2018.

Bright, Timothy. 1586. A Treatise of Melancholie. London: Printed by Thomas Vautrollier.

Coeffeteau, Nicolas. 1621. A Table of Humane Passions with Their Causes and Effects. London: Printed by Nicholas Okes.

Coole, Diana H., and Samantha Frost (eds.). 2010. New Materialisms: Ontology, Agency, and Politics. Durham: Duke University Press.

Debru, Armelle. 2015. Physiology. In The Cambridge Companion to Galen, ed. R.J. Hankinson, 263-282. Cambridge: Cambridge University Press.

Ferrand, Jacques. 1640. Erotomania: Or, A Treatise Discoursing of the Essence, Causes, Symptomes, Prognosticks, and Cure of Love, or Erotique Melancholy. Oxford: Printed by L. Lichfield.

Krasnow, Mark A., and Jack L. Feldman. 2016. The Peptidergic Control Circuit for Sighing. Nature 530: 293-297.

LaBelle, Brandon. 2014. Lexicon of the Mouth: Poetics and Politics of Voice and the Oral Imaginary. London: Bloomsbury.

Leys, Ruth. 2011. The Turn to Affect: A Critique. Critical Inquiry 37: 434-472.

Li, Peng, and Kevin Yackle. 2017. Sighing. Current Biology 27: R83-Rl02.

Lindemann, Mary. 1999. Medicine and Society in Early Modern Europe. Cambridge: Cambridge University Press.

Malone, Edmond (ed.). 1821. The Plays and Poems of William Shakespeare, vol. III. London: Printed for F.C. and J. Rivington et al.

Mazzio, Carla. 2009. The History of Air: Hamlet and the Trouble with Instruments. South Central Review 26: 153-196.

Mullaney, Steven. 2007. Affective Technologies: Toward an Emotional Logic of the Elizabethan Stage. In Environment and Embodiment in Early Modern 
England, ed. Mary Floyd-Wilson and Garrett A. Sullivan, 71-89. Basingstoke: Palgrave Macmillan.

Murray Kinsman, J. 1927. The History of the Study of Respiration. Presented to the Innominate Society. http://innominatesociety.com/Articles/The $\% 20$ History\%20of\%20the\%20Study\%20of\%20Respiration.htm. Accessed 27 Apr 2018.

Paster, Gail Kern. 2004. Humoring the Body: Emotions and the Shakespeare Stage. Chicago: University of Chicago Press.

Paster, Gail Kern, Katherine Rowe, and Mary Floyd-Wilson (eds.). 2004. Reading the Early Modern Passions: Essays in the Cultural History of Emotion. Philadelphia: University of Pennsylvania Press.

Plamper, Jan. 2010. The History of Emotions: An Interview with William Reddy, Barbara Rosenwein, and Peter Stearns. History and Theory 49: 237-265.

Radford, Tim. 2016. A Sigh Is Not Just a Sigh-It's a Fundamental LifeSustaining Reflex. The Guardian, February 8.

Ramirez, Jan-Marino. 2014. The Integrative Role of the Sigh in Psychology, Physiology, Pathology, and Neurobiology. Progress in Brain Research 209: 91-129.

Reddy, William. 2001. The Navigation of Feeling: Framework for the History of Emotions. Cambridge: Cambridge University Press.

Rosenwein, Barbara H. 2006. Emotional Communities in the Early Middle Ages. Ithaca: Cornell University Press.

Rutter, Carol Chillington. 2001. Enter the Body: Women and Representation on Shakespeare's Stage. London and New York: Routledge.

Rylance, Mark. 2009. Radiolab Blog. No. 14: The Four Groans. WNYC. The interview with Rylance starts at min 3, sec 20. http://bufvc.ac.uk/shakespeare/index.php/title/av73669. Accessed 8 Jan 2018.

Sale, Carolyn. 2006. Eating Air, Feeling Smells: Hamlet's Theory of Performance. Renaissance Drama 35: 145-168.

Scheer, Monique. 2012. Are Emotions a Kind of Practice (and is That What Makes Them Have a History)? A Bourdieuian Approach to Understanding Emotion. History and Theory 51 (2): 193-220.

Schoenfeldt, Michael C. 1999. Bodies and Selves in Early Modern England: Physiology and Inwardness in Spenser, Shakespeare, Herbert, and Milton. Cambridge: Cambridge University Press.

Shakespeare, William. 1987, reissued 2008. Hamlet, ed. G.R. Hibbard. Oxford: Oxford University Press.

Shakespeare, William. 2002. King Richard II, ed. Charles R. Forker. London: Bloomsbury.

Shakespeare, William. 2006. Hamlet, ed. Ann Thompson and Neil Taylor. London: Bloomsbury. 
Stern, Tiffany. 2004. Making Shakespeare: From Stage to Page. London and New York: Routledge.

Strier, Richard. 2011. The Unrepentant Renaissance: From Petrarch to Shakespeare to Milton. Chicago: University of Chicago Press.

"suspiration." OED Online. Oxford: University Press. www.oed.com. Accessed 26 Apr 2018.

"transfer." OED Online. Oxford University Press. www.oed.com. Accessed 27 Apr 2018.

Viney, William, Felicity Callard, and Angela Woods. 2015. Critical Medical Humanities: Embracing Entanglement, Taking Risks. Medical Humanities 41: $2-7$.

Vlemincx, Elke, et al. 2010a. Respiratory Variability Preceding and Following Sighs: A Resetter Hypothesis. Biological Psychology 84: 82-87.

Vlemincx, Elke, et al. 2010b. Take a Deep Breath: The Relief Effect of Spontaneous and Instructed Sighs. Physiology \& Behavior 101: 62-73.

Vlemincx, Elke, Ilse Van Diest, and Omer Van den Bergh. 2015. Emotion, Sighing, and Respiratory Variability. Psychophysiology 52: 657-666.

Walsh, Marcus. 1997. Shakespeare, Milton and the Eighteenth-Century Literary Editing. Cambridge: Cambridge University Press.

West, John. 2014. Galen and the Beginnings of Western Physiology. American Journal of Physiology-Lung Cellular and Molecular Physiology 307: L121-L128.

White, Robert S., and Ciara Rawnsley. 2015. Discrepant Emotional Awareness in Shakespeare. In The Renaissance of Emotion: Understanding Affect in Shakespeare and His Contemporaries, ed. Richard Meek and Erin Sullivan, 241-263. Manchester: Manchester University Press.

Whitehead, Anne, and Angela Woods. 2016. Introduction. In The Edinburgh Companion to the Critical Medical Humanities, ed. Anne Whitehead et al., 1-31. Edinburgh: Edinburgh University Press.

Woods, Angela. 2011. The Limits of Narrative: Provocations for the Medical Humanities. Medical Humanities 37: 73-78.

Wright, Thomas. 1604. The Passions of the Minde in General. London: Printed by Valentine Simmes and Adam Islip. 
Open Access This chapter is licensed under the terms of the Creative Commons Attribution 4.0 International License (http://creativecommons.org/licenses/ by $/ 4.0 /$ ), which permits use, sharing, adaptation, distribution and reproduction in any medium or format, as long as you give appropriate credit to the original author(s) and the source, provide a link to the Creative Commons license and indicate if changes were made.

The images or other third party material in this chapter are included in the chapter's Creative Commons license, unless indicated otherwise in a credit line to the material. If material is not included in the chapter's Creative Commons license and your intended use is not permitted by statutory regulation or exceeds the permitted use, you will need to obtain permission directly from the copyright holder.

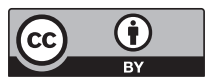

